\title{
Host specificity and metamorphosis of the glochidium of the freshwater mussel Unio tumidiformis (Bivalvia: Unionidae)
}

\author{
Joaquim Reis ${ }^{1,2}$, Maria João Collares-Pereira ${ }^{1}$ and Rafael Araujo ${ }^{3}$ \\ ${ }^{1}$ Universidade de Lisboa, Faculdade de Ciências, Centro de Biologia Ambiental, Lisboa, Portugal; \\ ${ }^{2}$ Instituto Português de Malacologia, Zoomarine, Albufeira, Portugal; \\ ${ }^{3}$ Museo Nacional de Ciencias Naturales, CSIC, José Gutiérrez Abascal, Madrid, Spain
}

\begin{abstract}
The glochidium larvae of freshwater mussels of the family Unionidae need to find suitable hosts to attach themselves and metamorphose into free-living juveniles. The specificity of the host-parasite relationship was investigated for the Iberian Unio tumidiformis Castro, 1885 by means of experimental infections and also by analyzing naturally infected fish. The process of encapsulation of glochidia was studied using scanning electron microscopy. Unio tumidiformis has proven to be an unusual host-specific unionid mussel, apparently parasitizing only fish of the genus Squalius Bonaparte, 1837. Successful encapsulation or complete metamorphosis was observed in five fish taxa: S. aradensis (Coelho, Bogutskaya, Rodrigues et Collares-Pereira), S. caroliterti (Doadrio), S. pyrenaicus (Günther), S. torgalensis (Coelho, Bogutskaya, Rodrigues et Collares-Pereira) and S. alburnoides (Steindachner) complex (only for the nuclear hybrids with at least one copy of the $S$. pyrenaicus genome). Complete metamorphose was achieved in 6 to 14 days at mean temperatures ranging from 21.8 to $26.1^{\circ} \mathrm{C}$. The current study provides support for cell migration being the main force of cyst formation and shows the influence of potential host's genome in response to the infection process to determine the success of the metamorphosis.
\end{abstract}

Keywords: Mollusca, larvae, encapsulation, juvenile, temperature, Iberian Squalius

The life cycle of most freshwater mussel species of the family Unionidae includes a temporary but obligatory parasitic stage, in which the larvae (glochidia) attach to the external surface of a suitable host and metamorphose into free-living juveniles (e.g. Kat 1984, Barnhart et al. 2008). Only two species are known to metamorphose without a parasitic stage in the wild (Barfield and Watters 1998; N. Johnson - personal comments). The advantages of the larval stage include protection, nutrition and dispersion, playing a key role in the evolutionary history of the group.

Mussel glochidia parasitize mostly fish hosts (Watters and O'Dee 1998), attaching to their gills, fins and body surface. The host specificity of the glochidia and their preferred site of attachment significantly vary between species. Some species are known to parasitize only a few fish species, whereas others exploit a wide range of potential hosts (Lefevre and Curtis 1912, Berrie and Boize 1985, Haag and Warren Jr. 1997, Araujo et al. 2001, Blažek and Gelnar 2006, Taeubert et al. 2012a,b). Glochidia equipped with hooks mainly encapsulate on the fish fins and body surface of many host species. Hookless glochidia usually attach to gills of a reduced number of hosts (Lefevre and
Curtis 1912, Berrie and Boize 1985, Pekkarinen and Englund 1995, Araujo et al. 2002, Barnhart et al. 2008).

After attachment to the appropriate host, the glochidium is enclosed in a cyst. It has been demonstrated that the cyst is formed by surrounding the glochidium exclusively by host tissue (Hoggarth and Gaunt 1988, Nezlin et al. 1993, Rogers-Lowery and Dimock 2006). For this reason, the process should rather be called encapsulation than encystment (Hoggarth and Gaunt 1988). In fact, very little is still known about the actual process of encapsulation and metamorphosis (Araujo et al. 2002, Rogers-Lowery and Dimock 2006).

The freshwater mussel Unio tumidiformis Castro, 1885 was considered by most authors as a synonym of the central European Unio crassus Phillipson, 1788. Nevertheless, its occurrence in the Iberian Peninsula has been questioned (Haas 1940, 1969, Ramos 1998, Pérez-Quintero et al. 2004, Reis 2006, Araujo et al. 2009). Recently, the validity of $U$. tumidiformis has been confirmed and the species has been redescribed by Reis and Araujo (2009).

These authors also reviewed several biological features of this mussel, but others remain virtually unknown, including its life cycle. According to Reis and Araujo

Address for correspondence: J. Reis, Instituto Português de Malacologia, Zoomarine, EN125, Km65 Guia, $8201-864$ Albufeira, Portugal. Phone: +351 964723114; Fax: +351 289560300; E-mail: joaqreis@gmail.com 
(2009), U. tumidiformis does not produce true conglutinates. This species is restricted to the south-west of the Iberian Peninsula and lives in temporary Mediterraneantype streams (Reis and Araujo 2009).

Since $U$. tumidiformis was previously considered a synonym of $U$. crassus, it was protected under the European Habitats Directive (Annexes II and IV). However, the restricted distribution of $U$. tumidiformis, its endemic character and occurrence in an area strongly affected by desertification, all reinforce its endangered status. The knowledge of its parasitic life stage is crucial for any effort towards the species conservation, by allowing both conservation measures for its hosts and captive breeding programs.

The fish fauna in the Iberian Peninsula is particularly diverse, especially in the south-western area where $U$. $t u$ midiformis occurs, and is characterized by some endemic species with rather limited distribution areas (Leunda et al. 2009). It can be assumed that the evolutionary history leading to patterns of diversification of fish species has been reflected in the number of hosts of each mussel species. The spreading of non-native species in recent decades has changed fish assemblages in most inland waters in Iberian Peninsula (reviewed in Ribeiro et al. 2009). The degree of association between $U$. tumidiformis and the native fish fauna, which is dominated by cyprinid species, may determine the impact of the recent changes on the future conservation of the mussel.

The objectives of this study were i) to determine suitable hosts for $U$. tumidiformis, ii) to evaluate the specificity level of the host-parasite relationship, and iii) to describe the structural changes of the host tissue surface and the glochidia during the metamorphosis.

\section{MATERIALS AND METHODS}

\section{Sampling}

Adult mussels were collected from the following localities in the south-west of the Iberian Peninsula (Fig. 1): River Vascão in 2006 (Guadiana basin, 37 $30^{\circ} 55^{\prime \prime} \mathrm{N} ; 7^{\circ} 34^{\prime} 53^{\prime \prime} \mathrm{W}$ ) and in 2007 from another site of this river $\left(37^{\circ} 30^{\prime} 05^{\prime \prime} \mathrm{N} ; 7^{\circ} 41^{\prime} 27^{\prime \prime} \mathrm{W}\right)$, as well as from the River São Pedro (Guadiana basin, $38^{\circ} 4^{\prime} 40.73^{\prime}$ 'N; $7^{\circ} 17^{\prime} 45^{\prime \prime} \mathrm{W}$ ) and River Marateca (Sado basin, 38 $34^{\prime} 47^{\prime \prime} \mathrm{N}$; $\left.8^{\circ} 37^{\prime} 16^{\prime \prime} \mathrm{W}\right)$. To determine gravid females, the valves of each specimen were slightly opened in the field to check for the presence of mature glochidia in the marsupia. Only females with very tumid and whitish marsupia were then selected for the experiments. Glochidia were used during the first 24 hours after mussel collection. When this was not possible, for instance because fish were not ready for infection, females were kept in 50-100 litres (1) aquaria with a sandy bottom and a weak current maintained by an internal water pump until glochidia were used for experiments. All mussels were returned to the locality of capture after obtaining the glochidia.

Fish species for experimental infection were selected in 2006 to include a wide range of genera, and in 2007 to embrace all possible variability within genera found to serve as suitable hosts of glochidia in experiments carried out in 2006. Since

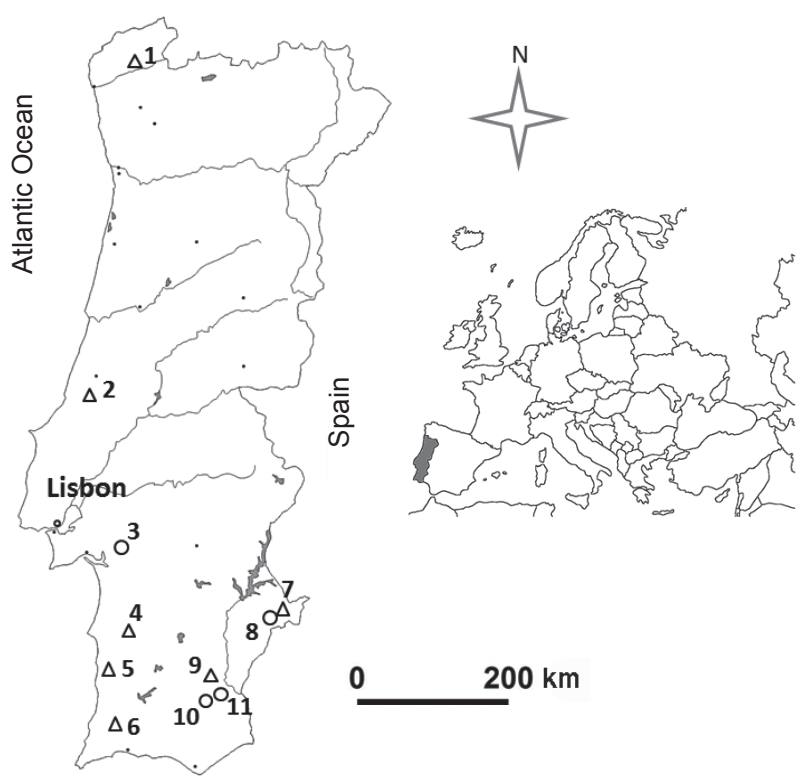

Fig. 1. Collection sites in Portugal. $\Delta$ Fish site. $\circ$ Fish and mussel site. 1 - Pêgo; 2 - Lis; 3 - Marateca; 4 - Sado; 5 - Torgal; 6 - Odelouca; 7 - Safareja; 8 - São Pedro; 9 - Oeiras; 10, 11 - Vascão.

the study was designed before the publication of Robalo et al. (2007), the new genera described by these authors to accommodate Iberian taxa (Achondrostoma, Iberochondrostoma and Pseudochondrostoma) were not taken into consideration; the corresponding species were initially selected to represent the single genus Chondrostoma Agassiz.

Fish were collected by electrofishing, targeting for sites without mussels to avoid previous contact with glochidia. However, some species could only be obtained from sites where mussels were present, so we tried to collect all necessary fish before the mussels' reproductive period (roughly April to July). Specimens of distinct species had to be collected from several drainages in Portugal because of the high inter-basin differentiation of fish fauna in the Iberian Peninsula (Table 1, Fig. 1). Small Guadiana barbels smaller than $10 \mathrm{~cm}$ in total length could not be identified to the species level reliably; therefore, we refer to those specimens as Luciobarbus spp. following Filipe et al. (2004). All fish were kept in aquaria for at least two weeks prior to use in experiments to ensure that all individuals were free of glochidia at the beginning of the experiments. Fish were fed daily with commercial food prior to, but not during the experiments.

\section{Experimental Design}

All experiments, except for the ones with Anaecypris hispanica (Steindachner), were performed in two recirculating systems consisting of nine 301 aquaria each, without substrate and under $12 \mathrm{~h} \mathrm{light/dark} \mathrm{illumination.} \mathrm{Temperature} \mathrm{was} \mathrm{maintained}$ constant during each experiment (between 21.4 and $26.1^{\circ} \mathrm{C}$ ) using a common thermostat connected to one heater in each system. Higher temperatures were reached by naturally higher room temperature later in the breeding season. In each system one aquarium was left without fish and used as control to ensure that no juveniles or glochidia would circulate between aquaria despite the outflow meshes and filtration systems. 
Table 1. Results of the experimental infections with Unio tumidiformis glochidia. Luciobarbus spp. refers to Guadiana barbels measuring less than $10 \mathrm{~cm}$ in total length belonging to some of the following species: L. comizo, L. microcephalus, L. sclateri and L. steindachneri. Anaecypris hispanica specimens were born in captivity; capture site of progenitors is indicated.

\begin{tabular}{|c|c|c|c|c|c|c|c|c|c|}
\hline Fish species & River Basin & River & $\mathrm{N}$ & Replicates & $\begin{array}{l}\text { Fish standard } \\
\text { length } \\
\pm \mathrm{SD}(\mathrm{cm})\end{array}$ & $\begin{array}{l}\text { Days to } \\
\text { transform }\end{array}$ & $\begin{array}{l}\text { Number of } \\
\text { juveniles }\end{array}$ & $\begin{array}{l}\text { Mean temperature } \\
\pm \mathrm{SD}\left({ }^{\circ} \mathrm{C}\right)\end{array}$ & Day degrees \\
\hline \multicolumn{10}{|l|}{ Hosts } \\
\hline Squalius alburnoides (hybrid) & Guadiana & Oeiras & 1 & 1 & 4.2 & $6-7$ & 5 & $26.1 \pm 2.0$ & $157-183$ \\
\hline Squalius alburnoides (hybrid) & Guadiana & Vascão & 2 & 1 & $4.7 \pm 0.5$ & $8-10$ & 111 & $23.9 \pm 0.2$ & $191-239$ \\
\hline Squalius alburnoides (hybrid) & Guadiana & Vascão & 1 & 1 & 10.1 & 8 & 28 & $22.8 \pm 0.7$ & 182 \\
\hline Squalius alburnoides (hybrid) $\dagger$ & Sado & Sado & 2 & 1 & $4.5 \pm 0.6$ & - & - & $25.0 \pm 0.2$ & - \\
\hline Squalius aradensis $!$ & Arade & Odelouca & 9 & 2 & $7.6 \pm 0.9$ & - & - & $22.3 \pm 0.1$ & - \\
\hline Squalius carolitertii & Pego & Pego & 2 & 1 & $9.4 \pm 0.8$ & 10 & 271 & $24.9 \pm 1.9$ & 249 \\
\hline Squalius carolitertii & Pego & Pego & 3 & 1 & $7.2 \pm 2.0$ & 7 & 141 & $25.5 \pm 2.0$ & 178 \\
\hline Squalius pyrenaicus $\dagger$ & Guadiana & Oeiras & 2 & 1 & $9.8 \pm 0.6$ & - & - & $22.3 \pm 0.0$ & - \\
\hline Squalius pyrenaicus & Sado & Marateca & 3 & 1 & $8.3 \pm 2.0$ & 7 & 409 & $25.5 \pm 2.0$ & 178 \\
\hline Squalius torgalensis & Mira & Torgal & 4 & 1 & $7.3 \pm 0.9$ & $11-13$ & 74 & $21.8 \pm 1.1$ & $240-283$ \\
\hline Squalius torgalensis & Mira & Torgal & 4 & 1 & $7.4 \pm 0.5$ & $11-14$ & 31 & $21.9 \pm 1.2$ & $241-307$ \\
\hline \multicolumn{10}{|l|}{ Non-Hosts } \\
\hline Achondrostoma oligolepis & Lis & Lis & 4 & 1 & $6.9 \pm 0.3$ & - & - & $23.9 \pm 0.2$ & - \\
\hline Anaecypris hispanica & Guadiana & Safareja & 6 & 2 & $<6.0$ & - & 0 & $21.4 \pm 1.7$ & - \\
\hline Anguilla anguilla & Guadiana & Vascão & 1 & 1 & 23.0 & - & 0 & $25.0 \pm 0.2$ & - \\
\hline Cobitis paludica & Guadiana & São Pedro & 9 & 3 & $6.5 \pm 0.5$ & - & - & $25.0 \pm 0.2$ & - \\
\hline Iberochondrostoma lemmingi & Guadiana & São Pedro & 8 & 2 & $6.6 \pm 0.6$ & - & 0 & $25.0 \pm 0.2$ & - \\
\hline Lepomis gibbosus & Guadiana & Vascão & 2 & 1 & 6.3 & - & 0 & $25.0 \pm 0.2$ & - \\
\hline Luciobarbus microcephalus & Guadiana & Vascão & 1 & 1 & 14.2 & - & 0 & $25.0 \pm 0.2$ & - \\
\hline Luciobarbus spp. & Guadiana & Oeiras & 4 & 1 & $4.1 \pm 0.3$ & - & 0 & $23.0 \pm 0.7$ & - \\
\hline Luciobarbus spp. & Guadiana & Vascão & 18 & 3 & $5.1 \pm 1.2$ & - & 0 & $\begin{array}{c}23.0 \pm 0.7 \\
-26.1 \pm 2.0 *\end{array}$ & - \\
\hline Squalius alburnoides AA & Guadiana & Vascão & 7 & 3 & $3.7 \pm 0.4$ & - & 0 & $\begin{array}{c}21.4 \pm 1.7 \\
-26.1 \pm 2.0 *\end{array}$ & - \\
\hline
\end{tabular}

$\uparrow$ All specimens died by day $6 ; \uparrow$ specimens died by day $7 ; *$ range of mean temperature of different experiment.

We used the two systems to replicate experiments in similar but independent conditions; replicating the experiments was particularly important to rule out possible false negative results caused by previous immunization. The experiments with $A$. hispanica were performed in independent aquaria at the Parque Natural do Vale do Guadiana. Except for the fact that artificial heating was not used, the conditions were similar to the previous experiments.

Glochidia were extracted from females by flushing the marsupia with water. The glochidia activity was tested with salt: mature and active glochidia snapped their valves repeatedly shortly after contact with the salt. Active glochidia from two or three females were put in a small volume of water together with up to 20 fish and allowed to infect them for about $15 \mathrm{~min}$ under heavy aeration. New glochidia from new females were used for each set of fish. The infected fish specimens were transferred to the aquaria separating them by species, with two systems as replicates. A maximum of one large specimen or five small ones were maintained in each aquarium.

Apart from different host species (the primary factor analysed), we tested metamorphosis success (measured as the presence of juveniles in the aquarium or the presence of encapsulated glochidia on fish that died prematurely) on hosts from different rivers and basins, using glochidia from mussels coming from different basins and considering the two most common genomotypes of Squalius alburnoides (Steindachner) in southern populations (Table 1) - both the nuclear diploid and triploid hybrids (PA and PAA) - and the nuclear non-hybrid
(AA) genomotypes, separately. In fact, AA individuals can be phenotypically distinguished from all the remaining nuclear hybrid specimens (Collares-Pereira and Coelho 2010).

Each aquarium was siphoned daily through sequential 200 and $150 \mu \mathrm{m}$ meshes. We checked for juveniles and counted them using a binocular lens system. Experiments were only terminated when at least 3 days passed from last juvenile drop-off, or up to 4 weeks after infection in aquaria with no record of juvenile drop-off. All fish specimens that died during experiments were checked for glochidia on gills, fins and body surface. Observations were immediately performed using a binocular lens system and a light microscope.

\section{Natural infection}

In May 2007, we checked a minimum sample of 10 specimens (more if available) for each fish species collected by electrofishing at the River Marateca (Sado basin): Anguilla anguilla Linnaeus, Cobitis paludica de Buen, Iberochondrostoma lusitanicum (Collares-Pereira), Gambusia hoolbrooki Girard, Gasterosteus gymnurus Linnaeus, Lampetra sp., Lepomis gibbosus Linnaeus, Luciobarbus bocagei (Steindachner) and Squalius pyrenaicus (Günther). This is the only river known to have a population of Unio tumidiformis that is not sympatric to Unio delphinus Spengler, 1793 (J. Reis - unpublished data). This fact is important because the glochidia of these two species are virtually impossible to distinguish from each other when encapsulated by the host tissue. The fish were anaesthetized and sacrificed before removing the gills, which were immediately checked for glochidia under a binocular lens. We counted the glochidia on 
the gills of each fish and also checked for infection on fins and the body surface.

\section{Scanning electron microscopical (SEM) metamorphosis analysis}

Several specimens of the S. alburnoides complex and Luciobarbus spp. were experimentally infected as described before to follow the metamorphosis of glochidia to juveniles. Gills from infected fish were prepared for observation using SEM. Sacrificing hosts was required to study metamorphosis, therefore, observations were based on multiple individuals. Fish were lightly anesthetized and sacrificed at $0,1,2,5-6,12,24,48$ hours, 1 and 2 weeks after infection to remove the gills. The body surface and fins were checked for glochidia and cysts with the aid of a binocular lens and a light microscope. Gills were fixed in a $2 \%$ glutaraldehyde solution in a phosphate buffer $\mathrm{pH} 7.4$ for 24 hours at $4{ }^{\circ} \mathrm{C}$. After thoroughly rinsing with water, gills were dehydrated in graded series from $5 \%$ to $100 \%$ ethanol. Samples were dried in a Bio-Rad CPD E-2000 critical point dryer, mounted on aluminum stubs and sputter-coated with gold using a Bio-Rad SE 515 sputter-coating unit. Observations were made with a Phillips XL20 SEM at accelerating voltages of 20-30 kV.

\section{RESULTS}

\section{Host specificity}

During experimental infections, glochidia of Unio tumidiformis formed cysts and metamorphosed only on hosts of the genus Squalius (Table 1). Juveniles were obtained from all but one Squalius species tested (S. aradensis fish died prematurely), including $S$. carolitertii, which is not known to be sympatric with $U$. tumidiformis. Although not investigated in detail, no significant differences seem to exist in infection rates between species, regardless of being sympatric or not.

Juvenile drop-off or glochidia encapsulation were observed in all specimens of $S$. alburnoides complex tested except in those specimens presenting the nuclear nonhybrid AA genome (Table 1). The consistency of these results among replicates and the fact that experimental conditions were uniform between the different genomotypes that were tested suggest that this was not an artifact and reflected a true host resistance.

We found no differences in successful cyst formation and metamorphosis success, measured as the presence or absence of juveniles at the end of the process, between hybrid S. alburnoides (PA and PAA) and S. pyrenaicus (PP), or from disconnected river basins (Guadiana and Sado) (Table 1), as well as between glochidia from mussels collected either in the Guadiana or in the Sado basin (data not shown). Encapsulation or juvenile drop-off was always observed regardless of mussel or host origin when fish of the genus Squalius (except nuclear non-hybrid, AA, S. alburnoides) were used.

\section{Natural infection}

Unio glochidia were found only in $S$. pyrenaicus specimens considering the 9 fish species that were collected in the River Marateca. Among these, $82 \%(n=11)$ had glochidia attached to their gills, with intensity of infection from 2 to 14 per fish. It is worth noting that in this river this was the only Squalius species identified.

\section{Metamorphosis}

All glochidia accomplished metamorphosis within 6 to 14 days with mean temperatures of different experiments ranging between 21.8 and $26.1^{\circ} \mathrm{C}$. Limited data restricted our ability to statistically support a negative correlation between water temperature and the length of metamorphosis, even though the fastest transformation ( 6 to 7 days) took place at a mean temperature of $26.1^{\circ} \mathrm{C}$ and the slowest ( 11 to 14 days) at $21.9^{\circ} \mathrm{C}$ (Table 1 ). In one of the experiments, there was an outbreak of the fish parasite Oodinium sp. No treatment was administrated while glochidia were attached to the fish. All these fish died on the first day of juvenile mussel drop-off, probably due to increased sensitivity to Oodinium, due to the injuries caused by glochidial detachment.

Glochidia attached successfully both to host and nonhost fish species (Fig. 2A), but encapsulation was observed only in suitable fish hosts. All glochidia on non-host fish species were rejected within one day. We detected only one encapsulated glochidium on a fin (Fig. 2B); all others were observed attached to the gills.

The following description of metamorphosis was based on SEM observations of the gills of infected S. alburnoides nuclear hybrid specimens maintained at a mean temperature of around $25^{\circ} \mathrm{C}$. Encapsulation started immediately after infection, but its rate varied greatly even within the same gill filament (Fig. 2C). Some fully developed cysts were observed one hour after infection, while others did not form until after five hours (Fig. 2C). Twenty four hours after infection all glochidia were either lost or encapsulated (Fig. 2D,E). At this point the cyst was composed of several layers of cells, thickly covering the glochidium shell. The same pattern was observed 48 hours after infection (Fig. 2F).

The fish epithelial cells in the vicinity of the glochidium attachment point were rounded and swollen during cyst formation, lacking the typical microridges of normal cells that could be seen in areas away from glochidia (Fig. 3A,B). The cells resumed the normal polygonal shape with microridges at the surface after the fish epithelium completely covered the glochidia (Fig. 3C,D).

The cyst clearly got thinner one week after infection, being composed of normally shaped epithelial cells (Fig. 4A). Most of the juvenile shell was already exposed two weeks after attachment. Several rounded and swollen cells were irregularly dispersed over its surface (Fig. 4B). At this stage juveniles are ready to drop-off. In the two weeks samples, a few empty glochidia attachment points were observed, left presumably after juvenile drop-off (Fig. 4C). 

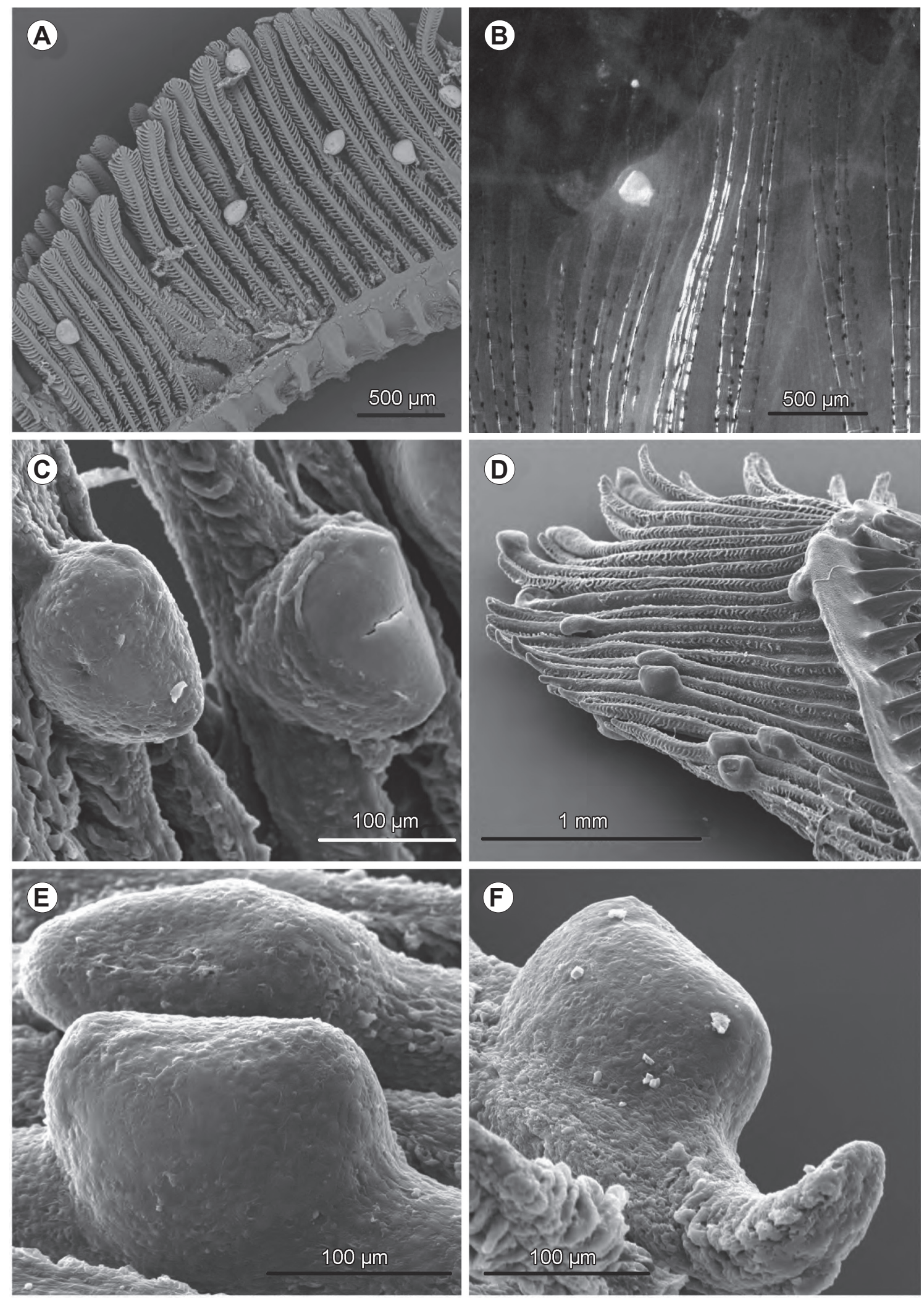

Fig. 2. Attachment of glochidia to host tissue and development of cyst (SEM and light microscope micrographs). A-glochidia on the gills immediately after attachment; $\mathbf{B}$ - glochidium attached and encapsulated to dorsal fin 24 hours after infection; $\mathbf{C}-$ cyst formation on the gills 5 hours after infection; note differences in the rate of encapsulation between glochidia; $\mathbf{D}, \mathbf{E}-$ cysts on the gills 24 hours after infection; $\mathbf{F}$ - cyst on the gills 48 hours after infection. 

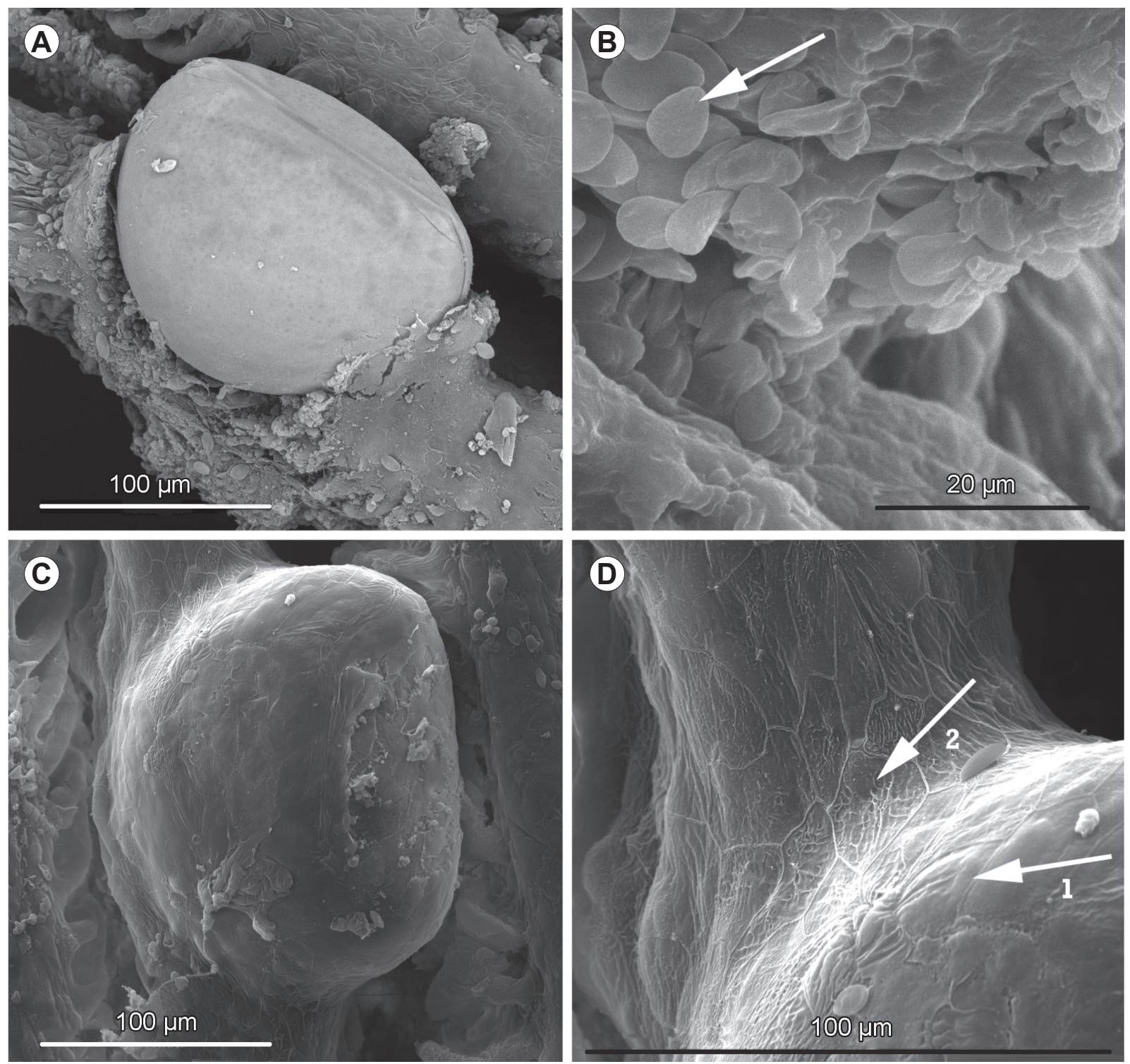

Fig. 3. Cell migration and types during encapsulation process (SEM micrographs). A - Growing cyst around glochidium. B - Swollen rounded migrating cells (arrow) on growing cyst. C - Fully formed cyst. D - Normal polygonal epithelial cells (1) with microridges (2) on fully formed cyst.

Freshly dropped-off juveniles had exactly the same shape and size as the glochidia, but initiated immediately to grow, with a small shell growth ring was already visible after some hours (Fig. 4D). Juveniles were very active, exhibiting the protruding foot in constant movement.

\section{DISCUSSION}

Freshwater mussels belonging to the subfamily Unioninae sensu Graf and Cummings (2006) are known to present a generalist host-parasite relationship (Watters and O'dee 1998). Previous studies on European Unio species supported this statement (Berrie and Boize 1985, Araujo et al. 2005, Blažek and Gelnar 2006, Taeubert et al. 2012a,b). Experimental infections with Unio crassus Philipsson, 1788 and Unio mancus Lamarck, 1819 re- vealed that their glochidia can metamorphose successfully on a broad range of fish species from different genera (Hochwald and Bauer 1990, Araujo et al. 2005, Taeubert et al. 2012a,b). However, glochidia from both species were found only in a restricted number of fish species in the wild (Engel and Wächtler 1989, Hochwald and Bauer 1990, Araujo et al. 2005, Taeubert et al. 2012b), suggesting a more ecologically driven specific host-parasite relationship.

Our results suggest that Unio tumidiformis is more host specific than any other known congeneric species, because its glochidia were able to successfully metamorphose exclusively on cyprinids of the genus Squalius. This observation was corroborated by both experimental infections and survey of wild fish hosts. It is interesting 

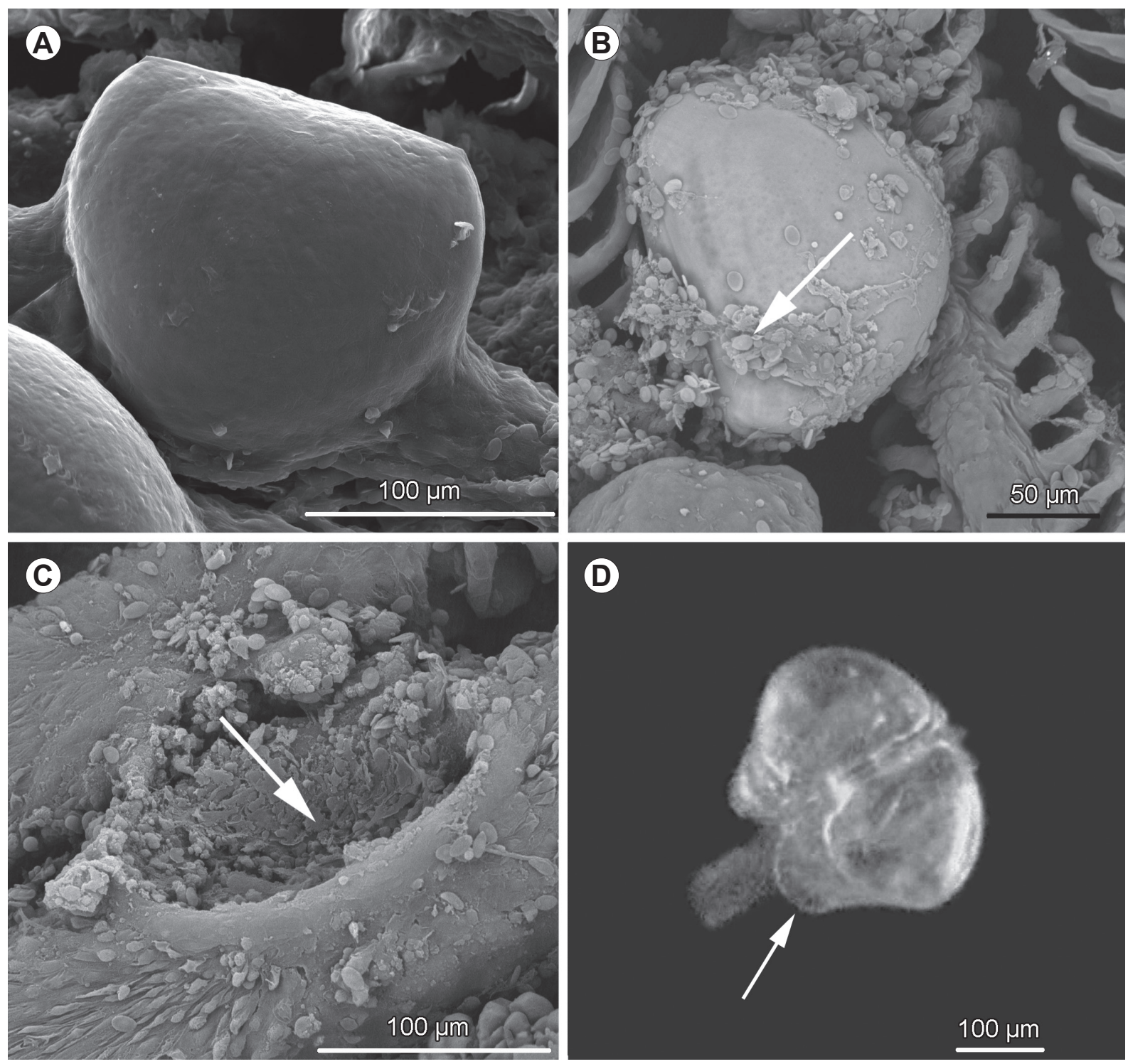

Fig. 4. Process leading to juvenile drop-off (SEM and light microscope micrographs). A - Cyst one week after infection. B - Ready to drop-off juvenile with scattered swollen rounded epithelial cells (arrow) around. $\mathbf{C}$-Attachment point (arrow) of glochidium after juvenile drop-off. D - One-day-old juvenile with small ring (arrow) of growing shell visible.

to note that Taubert et al. (2012b) found that U. crassus, a sister species of $U$. tumidiformis, seemed to parasitize preferably chub, Squalius cephalus (Linnaeus), even though metamorphosis was demonstrated in hosts of several genera (Douda et al. 2012, Taeubert et al. 2012b). However, unlike $U$. tumidiformis, it is not clear whether $U$. crassus uses consistently the same primary host (species or genus) as suggested by Douda et al. (2012), who determined the primary host of this species to be minnow Phoxinus phoxinus (Linnaeus).

In a given geographic region, unionid glochidia are usually non-selective towards different host species that belong to the same genus. In the present study, 9 to 13 (the species identity of the four barbels known to occur at Guadiana basin could not be determined in individu- als smaller than $10 \mathrm{~cm}$ ) of 19 native fish species potentially sympatric with $U$. tumidiformis were tested. This sample represented the most common fish genera in this area (Ribeiro et al. 2007), if estuarine and migratory species are not considered. Further studies are necessary to evaluate all the genera that Robalo et al. (2007) described to include the species previously assigned to Chondrostoma. Nevertheless, such a specific host-parasite relationship, already suggested by Reis and Araujo (2009), is very unusual within the Unioninae.

Although $U$. tumidiformis glochidium is hooked, a character associated with attachment to hard tissues like those of fins, we found that the species is almost exclusively a gill parasite. This is in agreement with what seems to be the general trend in species of Unio (see Ber- 
rie and Boize 1985, Engel and Wächtler 1989, Araujo et al. 2005, Blažek and Gelnar 2006), unlike other unionin genera (e.g. Anodonta Lamarck, 1799) that parasitize mainly fins and body surface (Dartnall and Walkey 1979, Blažek and Gelnar 2006). It is worth noting that the hooks of Unio larvae are smaller than those of Anodonta.

Most host-specific freshwater mussels belong to the family Margaritiferidae and the subfamilies Ambleminae and Lampsilinae. These mussels are mostly gill parasites, which is often argued to offer more protection to their hookless glochidia. This argument seems not to make sense for species with hooked glochidia like those of Unio, where many species show a tendency to attach mostly to the gills. The evidence suggests that there is a trend for host specialization in Unio reaching its peak with U. tumidiformis, accompanied by a preferred attachment of glochidia to the gills, which nevertheless cannot be entirely related to the glochidium morphology.

The Iberian Squalius alburnoides complex has an unidirectional hybrid origin coming from $S$. pyrenaicus (P genome) females and males from an unknown Anaecypris-like ancestor (A genome; reviewed in CollaresPereira and Coelho 2010). In southern populations, the most common genomotypes have the $\mathrm{P}$ and the A genomes in variable proportions, as diploid (PA), triploid (PAA) and rarely tetraploid (PPAA) specimens. Individuals lacking the $\mathrm{P}$ contributing genome constitute an almost allmale lineage, the nuclear non-hybrid form (AA). These diploids exhibit, as do the remaining nuclear hybrids, mtDNA from $S$. pyrenaicus and are presently generated only within the hybrid complex by meiotic hybridogenesis and have been considered to reconstitute the genome of the complex paternal ancestor (Collares-Pereira and Coelho 2010).

The fact that $U$. tumidiformis glochidia could not metamorphose on specimens bearing the nuclear AA genome is noteworthy and should be further investigated, since it may reinforce the specificity of the host-parasite relationship. It also suggests that the mechanisms of rejection of glochidia by resistant fish species are genetically driven and thus fundamentally different from those leading to acquired resistance. The formation of abnormal cysts in both cases as reported by several authors (for review see Rogers-Lowery and Dimock 2006) could be explained as the ongoing wound-healing process (Arey 1932) before glochidia rejection. However, it also supports Rogers-Lowery and Dimock (2006) statement that glochidia influence themselves the cyst formation: if only a wound-healing process was involved, it would cause the formation of identical cysts in both hosts and non-hosts.

The process of glochidia encapsulation is clearly associated with the host's epithelial cell migration rather than by proliferation (Rogers-Lowery and Dimock 2006), being comparable to the process of wound healing. Migration of cells allows much faster response than cell proliferation alone would, minimizing exposure to the environment. Most previous studies found that complete encapsulation is achieved only a few hours after attachment (Araujo et al. 2002, Rogers-Lowery and Dimock 2006).

In the present study completely encapsulated glochidia were observed as early as one hour after attachment, faster than cell proliferation alone would allow. The migratory cells are epithelial cells that have lost their normal flat shape and surface microridges acquired a rounded and swollen appearance.

The same phenomenon was observed in the wound healing process by Rogers-Lowery and Dimock (2006). These cells were observed during the course of the encapsulation of $U$. tumidiformis glochidia, hence providing evidence that cell migration is the underlying process. The fact that these cells were observed again just before drop-off is new and may indicate that juvenile drop-off may trigger a new wound healing process.

In summary, U. tumidiformis has proven to be an unusual host-specific unionid species, apparently parasitizing only fish of the genus Squalius. The present study documented migration of cells being the main force of cyst formation and for the influence of the genome of potential hosts in conjunction with an unknown glochidium factor in determining the success or failure of metamorphosis.

Acknowledgments. We thank Dr. M. Judite Alves and the Museu Bocage in Lisbon for providing logistic conditions for performing experiments with fish. Ricardo Calado provided valuable help with the experimental set-up. We are indebted to numerous people for mussel and fish collection help; special thanks are due to Carlos Carrapato and all the staff at the Parque Natural do Vale do Guadiana, to M. Judite Alves, Hugo Gante, José Rodrigues and Daniel Pires. Prof. Alexandre Valente provided us with specimens of Squalius carolitertii. SEM micrographs were prepared by Alberto Jorge, Laura Tormo and Marta Furió (MNCN Madrid, Spain). Plates were compiled by J. Muñoz from the photography facility of the MNCN. Nathan Johnson reviewed the English. Finnally, we thank Tomáš Scholz, Jürgen Geist and an anonymous reviewer for valuable comments that significantly improved this paper. The author J. Reis benefited from a doctoral grant from FCT (SFRH/BD/12687/2003).

\section{REFERENCES}

Araujo R., Bragado D., Ramos M.-Á. 2001: Identification of the river blenny, Salaria fluviatilis, as a host to the glochidia of Margaritifera auricularia. J. Mollusc. Stud. 67: 128-129.

Araujo R., Cámara N., Ramos M.-Á. 2002: Glochidium metamorphosis in the endangered freshwater mussel Margaritifera auricularia (Spengler, 1793): a histological and scanning electron microscopy study. J. Morphol. 254: 259-265.

Araujo R., Gómez I., Machordom A. 2005: The identity and biology of Unio mancus Lamarck, 1819 (=U. elongatulus) (Bi- 
valvia: Unionidae) in the Iberian Peninsula. J. Mollusc. Stud. 71: $25-31$.

Araujo R., Reis J., Machordom A., Toledo C. Madeira M.J., Gómez I., Velasco J.C., Morales J., Barea J.M., Ondina P., Ayala I. 2009: Las náyades de la península Ibérica. Iberus, 27: 7-72.

Arey L.B. 1932: Certain basic principles of wound healing. Anat. Rec. 51: 299-313.

Barfield M.L., Watters G.T. 1998: Non-parasitic life cycle in the green floater, Lasmigona subviridus (Conrad, 1835). Triannual Unionid Rep. 16: 22.

Barnhart M.C., Haag W.R., Roston W.N. 2008: Adaptations to host infection and larval parasitism in Unionoida. J. N. Am. Benthol. Soc. 27: 370-394.

Berrie A., Boize B. 1985: The fish hosts of Unio glochidia in the River Thames. Verh. Int. Verein. Limnol. 22: 2712-2716.

Blažek R., Gelnar M. 2006: Temporal and spatial distribution of glochidial larval stages of European unionid mussels (Mollusca: Unionidae) on host fishes. Folia Parasitol. 53: 98-106.

Collares-Pereira M.J., Coelho M.M. 2010: Reconfirming the hybrid origin and generic status of the Iberian cyprinid complex Squalius alburnoides. J. Fish Biol. 76: 707-715.

Crespo-López M.E., Duarte T., Dowling T.E., Coelho M.M. 2006: Modes of reproduction of the hybridogenetic fish Squalius alburnoides in the Tejo and Guadiana rivers: an approach with microsatellites. Zoology 109: 277-286.

Dartnall H.J.G., Walkey M. 1979: The distribution of glochidia of the Swan mussel, Anodonta cygnea (Mollusca), on the threespined stickleback Gasterosteus aculeatus (Pisces). J. Zool. 89: 31-37.

Douda K., Horký P., BílÝ M. 2012: Host limitation of the thickshelled river mussel: identifying the threats to declining affiliate species. Anim. Conserv. 15: 536-544.

Engel H., Wächtler K. 1989: Some peculiarities in developmental biology of two forms of the freshwater bivalve Unio crassus in northern Germany. Arch. Hydrobiol. 115: 441-450.

Filipe A.F., Marques T., Seabra S., Tiago P., Ribeiro F., Moreira Da Costa L., Cowx I.G., Collares-Pereira M.J. 2004: Selection of priority areas for fish conservation in Guadiana River Basin, Iberian Peninsula. Conserv. Biol. 18: 189-200.

Graf D.L., Cummings K.S. 2006: Palaeoheterodont diversity (Mollusca: Trigonoida + Unionoida): what we know and what we wish we knew about freshwater mussel evolution. Zool. J. Linnean Soc. 148: 343-394.

HaAg W.R., Warren Jr. M.L. 1997: Host fishes and reproductive biology of 6 freshwater mussel species from the Mobile basin, USA. J. N. Am. Benthol. Soc. 16: 576-585.

HaAs F. 1940: A tentative classification of the Paleartic unionids. Field Mus. Nat. Hist., Zool. Ser. 24: 115-141.

HaAs F. 1969: Superfamilia Unionacea. Das Tierreich 88: 1-663.

Hochwald S., Bauer G. 1990: Untersuchungen zur Populationsökologie und Fortpfanzungsbiologie der Bachmuschel Unio crassus (Phil.) 1788. Schrift. Bayer. Landesamt Umweltschutz 97: 31-49.

Hoggarth M.A., Gaunt A.S. 1988: Mechanics of glochidial attachment (Mollusca: Bivalvia: Unionidae). J. Morphol. 198: 71-81.

Kat P.W. 1984: Parasitism and the Unionacea (Bivalvia). Biol. Rev. 59: 189-207.

Received 17 January 2013
Lefevre G., Curtis W. 1912: Reproduction and parasitism in the Unionidae. J. Exp. Zool. 9: 79-115.

Leunda P., Elvira B., Ribeiro F., Miranda R., Oscoz J., Alves M.J., Collares-Pereira M.J. 2009: International standardization of common names for Iberian endemic freshwater fishes. Limnetica 28: 189-202.

Lima P., Kovitvadhi U., Kovitvadhi S., Machado J. 2006: In vitro culture of glochidia from the freshwater mussel Anodonta cygnea. Invert. Biol. 125: 34-44.

Nezlin L.P., Cunjak R.A., Zotin A.A., Ziuganov V.V. 1993: Glochidium morphology of the freshwater pearl mussel (Margaritifera margaritifera) and glochidiosis of the Atlantic salmon (Salmo salar): a study by scanning electron microscopy. Can. J. Zool. 72: 15-21.

Pekrarinen M., Englund V.P. 1995: Description of unionacean glochidia in Finland, with a table aiding in their identification. Arch. Hydrobiol. 134: 515-531.

Pérez-Quintero J.C., Bech Taberner M., Huertas Dionisio J.L. 2004: Los moluscos de las aguas continentales de la provincia de Huelva (SO España). Iberus 22: 19-31.

RAMOS M.-Á. 1998: Implementing the habitats directive for mollusc species in Spain. J. Conchol., Spec. Public. 2: 125-132.

Reis J. 2006: Atlas dos Bivalves de Água Doce de Portugal Continental. Instituto da Conservação da Natureza, Lisboa, 130 pp.

Reis J., Araujo R. 2009: Redescription of Unio tumidiformis Castro, 1885 (Bivalvia, Unionidae), an endemism from the southwestern Iberian Peninsula. J. Nat. Hist. 43: 1929-1945.

Ribeiro F., Beldade R., Dix M., Bochechas J. 2007: Carta piscícola nacional. Direcção Geral dos Recursos Florestais-Fluviatilis, Lda. World Wide Web electronic publication, www. cartapiscicola.org, 09/2007.

Ribeiro F., Collares-Pereira M.J., Moyle P.B. 2009: Nonnative fish in the fresh waters of Portugal, Azores and Madeira Islands: a growing threat to aquatic biodiversity. Fish. Manag. Ecol. 16: 255-264.

Robalo J.I., Almada V.C., Levy A., Doadrio I. 2007: Re-examination and phylogeny of the genus Chondrostoma based on mitochondrial and nuclear data and the definition of 5 new genera. Mol. Phylogenet. Evol. 42: 362-272.

Robalo J.I., Santos C.S., Levy A., Almada V.C. 2006: Molecular insights on the taxonomic position of the paternal ancestor of the Squalius alburnoides hybridogenetic complex. Mol. Phylogenet. Evol. 30: 276-281.

Rogers-Lowery C.L., Dimock Jr R.V. 2006: Encapsulation of attached ectoparasitic glochidia larvae of freshwater mussels by epithelial tissue on fins of naïve and resistant host fish. Biol. Bull. 210: 51-63.

Taeubert J.E., Gum B., Geist J. 2012a: Host-specifity of the endangered thick-shelled river mussel (Unio crassus Philipsson 1788) and implications for conservation. Aquat. Conserv. Mar. Freshwat. Ecosyst. 22: 36-46.

Taeubert J.E., Martinez A.M.P, Gum B., Geist J. 2012b: The relationship between endangered thick-shelled river mussel (Unio crassus) and its host fishes. Biol. Conserv. 155: 94-103.

Watters G.T., O'Dee S.H. 1998: Metamorphosis of the freshwater mussel glochidia (Bivalvia: Unionidae) on amphibians and exotic fishes. Am. Midl. Nat. 139: 49-57. 